\title{
The Psychological Dynamics of Youth with Internet Addiction
}

\author{
Virgin Suciyanti Maghfiroh, Faqihul Muqoddam \\ Faculty of Psychology \\ Airlangga University, Surabaya \\ virgin.suciyanti.maghfiroh-2018@psikologi.unair.ac.id, fagihul.muqoddam-2018@psikologi.unair.ac.id
}

\begin{abstract}
Internet users are increasing over time. The increasing of internet users, especially for youth people, tends to create internet addiction in each user. Internet addiction in youth people is interesting to know their attitudes and behavior psychologically, because it is related to their daily conditions. This research was conducted to answer the psychological dynamics of youth people with internet addiction. To answer that, there are some research questions such as what factors make young people addicted to the internet? what do they feel when not using the internet? and what are the impacts of using the internet for them? The research method uses qualitative methods with narrative descriptive approaches. Data analysis using thematic data analysis. The results showed that 1) the need for affiliation, high curiosity about information, and online business became the reason youth people access the internet, 2) youth people feel anxious and loneliness when not accessing the internet, 3) the impact of accessing the internet such as sad and happy on their emotions that occur according to situations and conditions. In addition, researchers also found interesting things from their attitude who experienced boredom when often using the internet but failed for them to stop or reduce access to the internet. The conclusion that the internet now is a necessary for youth people, because the internet has a major impact on their psychological factors.
\end{abstract}

Keywords: internet addiction; internet need; psychological dynamics; youth

\begin{abstract}
Abstrak
Pengguna internet semakin bertambah dari waktu ke waktu. Jumlah penggunanaan internet yang semakin meningkat khususnya pada anak muda cenderung dapat menciptakan kecanduan internet pada diri masing-masing pengguna. Kecanduan internet pada anak muda menarik untuk diketahui sikap dan perilakunya secara psikologis, karena hal itu berkaitan dengan kondisi keseharian mereka. Penelitian ini dilakukan untuk menjawab dinamika psikologis anak muda yang kecanduan internet. Untuk menjawab hal itu, terdapat beberapa pertanyaan penelitian seperti faktor apa yang membuat anak muda kecanduan internet? apa yang mereka rasakan ketika tidak menggunakan internet? serta apa dampak dari penggunaan internet bagi mereka? Metode penelitian menggunakan metode kualitatif dengan pendekatan naratif deskripif. Analisis data menggunakan analisis data tematik. Hasil penelitian menunjukkan bahwa 1) kebutuhan untuk afliasi, keingintahuan yang tinggi terhadap informasi, dan bisnis online menjadi alasan anak muda mengakses internet, 2) anak muda merasa cemas dan kesepian ketika tidak mengakses internet, 3) dampak dari mengakses internet berupa perasaan sedih dan senang pada emosi mereka yang terjadi sesuai situasi dan kondisi. Selain itu, peneliti juga menemukan hal yang menarik dari sikap mereka yang mengalami kebosanan ketika sering bermain internet namun gagal bagi mereka untuk berhenti maupun mengurangi dalam
\end{abstract}


mengakses internet. Kesimpulan bahwa internet saat ini sudah menjadi kebutuhan anak muda, karena internet berdampak besar pada faktor psikologis mereka.

Kata Kunci: Kecanduan Internet; Kebutuhan Internet; Dinamika Psikologis; Anak Muda

\section{Introduction}

The current era of globalization now is demanding a change in the midst of society. Globalization is understood as the flow of industrialization, finance, culture, ideas, and communication technology (McKenzie, 2019). Suny Levin Institute (2013) said that technology plays an important role in pushing towards the process of globalization, especially in aspects of daily life in a country with an industrial society in it. In addition, technology can also encourage the development of an innovation (Gancia, 2012).

Internet users are increasing from time to time. The internet has developed rapidly over the last some decades in the world (Kuss et al., 2014) and radically has changed human lives (Poli, 2017). Hootsuite and We Are Social (2019) released the latest survey in January 2019 that internet users have reached 4,388 billion worldwide and as many as 150 million people in Indonesia. The survey results show that Internet users in Indonesia increase of 13\% from January 2018 to January 2019 from a total population of 268.2 million residents. Internet World Stats (2019) also released the latest results on 31 March 2019 by placing Indonesia as the 5th highest country with the most internet users in the world from 2,000,000 in December 2000 increasing to 143,260,000 on 31 March 2019.

Youth has a significant role in the development of globalization. Some changes that occurred in the 21st century made youth involved in local and global culture in the context of globalization (McKenzie, 2019). Youth is a period between childhood and adulthood that finds themselves in a complex social system from various elements of tradition, history, social demands, hopes and prospects for the individual's future and moves from one stage to another in life (Henze, 2015; Espejo \& Espindola, 2016). In the age range, youth are individuals who have an age range from 16 years to 30 years (UU Kepemudaan, 2009).

The increase in the community that using internet access aims to their sense of comfort in spending daily time with playing the internet untill making him an internet addict. In general, addiction is a part of biopsychosocial and has several different components, namely salience, mood modification, tolerance, withdrawal, conflict and relapse (Griffiths, 2005). The component models of addiction together contribute to explaining addiction behavior in depth and are useful in assessing the potential for internet addiction. Addictions have differences with each other in their development, for example internet addiction is different from drug confusion (Kuss et al., 2014).

Addiction can also be associated with uncontrolled desires, often losing control, feeling comfortable and passionate when using it and continuing to do it continuously despite experiencing problems due to these uses, addiction and internet abuse both produce consequences (Young, 2004). The term internet addiction that aims to pathological behavior was proposed by Dr. Ivan Goldberg, according to him, pathological behavior is a problematic, excessive and maladaptive use of the internet (Adalier \& Balkan, 2012). 
Young (1999) classifies internet addiction into five sub-types, namely addiction to cybersex, cyber relationship, net compulsions (including online stock trading, shopping, gambling), to search for information, and computer addiction for programming or game. Kimberly Young provides a way to diagnose internet addicts through the questions (Young, 2004).

Not only at the university level, internet addiction has also been widespread in high school students and vulnerable to being experienced by young people in general (Poli, 2017; Wallace, 2014). Youth who are addicted to the internet have a significant relationship with the psychological symptoms they experience (Poli, 2017; Adalier \& Balkan, 2012) and have a large impact on communication and interpersonal behavior of individuals (Sato, 2006).

Previous research this study in Indonesia is about the psychological dynamics of online users in Indonesia that focus on the interaction of self-concepts and online user online identity (Sandra, 2012). In addition, there are also studies of the psychological dynamics of gamers who experience online game addiction in college students (Hartedja, 2016). Although both of them are related to this research, but both of them have not explained in detail the psychological dynamics of youth who experience internet addiction which includes factors that can encourage internet use, the feelings experienced when accessing and not accessing the internet, and the impact of internet using.

Psychological dynamics is the study of human thoughts and behavior based on the concept of the soul dynamically. The concept of psychological dynamics has the principle that psychic functions are a play of strength. Scientists are required to be open-minded in considering operational principles related to the field of psychology (Ancona, 2009). While the Medical Dictionary for the Health Professions and Nursing (2012) defines the dynamics of psychology as a psychological approach related to the causes of behavior.

This study is important because the majority of internet users are those who are still classified as young people as explained by the Association of Indonesian Internet Service Providers (APJII, 2018) that internet users in Indonesia in 2018 are still dominated by young people that $91 \%$ are aged 15-19 years and $88.5 \%$ are 20-24 years of age population. Basically, youth are the next generation of a nation that has a high hope in the future, so that youth can determine the fate of the nation in the next few years. The connection between individuals who are addicted to the internet with the psychological dynamics they experience and the lack of similar studies in Indonesia is also the reason for this research.

Vulnerable youth experience internet addiction shows the research questions about how the psychological dynamics of young people with internet addiction? This research will answer this problem by describing several research results such as 1) the factors that make them often access the internet, 2) their feelings when not accessing the internet, and 3) the impact of using the internet for their lives psychologically. Everything will be explained and analyzed in this study in detail which then can become a guide for teachers and parents and all parties related to the life processes of young people in Indonesia.

\section{Method}

\section{Participants}

Young people with internet addiction were selected as participants in this study. To find out, some questions from Young (2004) are used in knowing and diagnosing young people who are addicted to the internet. Referring to the term youth by the UU Kepemudaan (2009), youth selected 
as participants are those aged 16 years to 30 years of their development in Indonesia. The appointment of participants was random by emphasizing the eight-step aspect proposed by Young above.

Young people are chosen as participants because they spend more time accessing the internet than any other age level. This was based on a recent survey by the Indonesian Internet Service Providers Association (APJII, 2018) which stated that users aged 15-19 were 91\% and aged 20-24 were $88.5 \%$ of the same age population. This is also due to the consideration that young people are most vulnerable to internet addiction (Wallace, 2014) because the internet is very important for the adolescents and child's daily life who are classified as young people (Mihajlov \& Vejmelka, 2017).

\section{Research Approach}

This research uses a qualitative method with a narrative psychology analysis approach. This approach is associated with finding out other people's experiences to be arranged neatly appropriate with the context of research that is being built through narratives about the life experiences of the participants which are then interpreted by researchers. Researchers only provide opportunities for participants to tell stories about an experience and summarize it as a conclusion from some the events that have been submitted (Wilig, 2008).

In context of this study, research results from the participants experience who are addicted to the internet during accessing online in their daily lives. The principle of narrative research in psychology is that we not only shape the world and ourselves, but our environment is shaped for us through the narration (Murray, 2003).

\section{Data Analysis}

Data analysis used in this study is a thematic analysis. This analysis is often used in the field of psychology and offers an easily accessible approach and flexible theoretically to analyzing qualitative data (Braun \& Clarke, 2006). Some steps in analyzing qualitative psychological data using thematic analysis can be seen below.

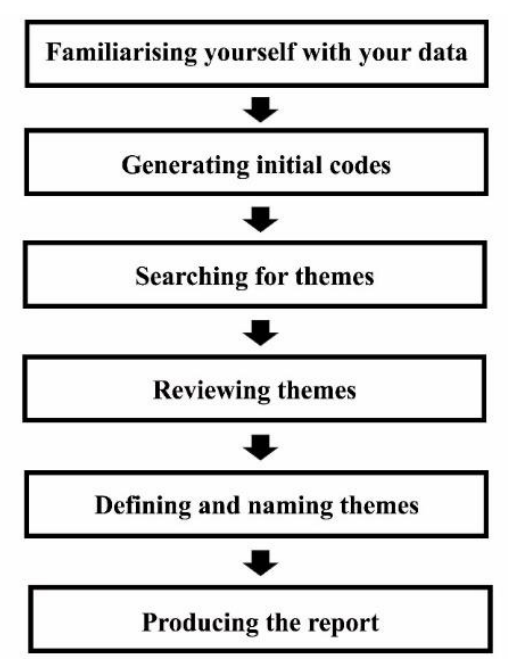

Figure 1. The Stage of Thematic Analysis (Braun \& Clarke, 2006) 


\section{Results and Discussion}

\section{Factors that Cause Internet Usage}

The factors that can make young people increasingly addicted to accessing the internet because they have 1) the need for affiliation, it is recognized that the existence of social media applications such as WhatsApp, Facebook and Instagram can help them in communication with other friends who are far away. 2) high curiosity about information. All information according to them is very important to be traced and searched for truth, because all information will be easy by only accessing the internet on handphone and laptops / computers. 3) online business. Although not all young people fill their online time by selling online, but this activity is increasing over time. This was discovered by the existence of various sites that serve buying and selling online.

"The internet makes it easy for me to communication with friends far from where I live, especially when Eid to contact friends, brothers, and family who are far away at home. With this, you can also keep the friendship in orther that not disconnected"

"A lot of information can be known through the internet. Anyway, it is very easy to seeking the information. Just type in a google search and everything will appear what we are looking for. This is beneficial for everyone, especially shy people like me"

"Thank God, my income comes partly from online business. I often spend internet quota just for buying and selling through the applications that have been scattered on the internet. I am quite helped by the existence of online sales service, because I can also focus on learning without selling around and without difficulty buying goods to the sales location."

Social networking sites are a forum for users to create individual public profiles which then interact with friends in real life and meet other people who have similar interests (Griffiths et al., 2014). But there is a paradox in its use, in addition to individuals want to feel safe online, they also want to share information with others so that it can affect their security online (Kempa, 2015).

Factors that can make the use of the internet increase, one of which is determined by the personality of someone who is able to encourage the use of the internet, especially social media with internet access (Liu et al., 2018). Someone will experience addiction or dependency if playing the internet can meet their needs (Wainner, 2018).

Social networking sites are the easiest step to connect to others people in various parts of the world (Veronica \& Samuel, 2015). The tendency in online social media is caused by strong social bond from the influence of the social environment and friends around (Zolkepli \& Kamarulzaman, 2015). The main purpose of high usage in online social media is related to social goals to improve social relationships, especially for an extrovert (Kuss \& Griffiths, 2011). 
Different with antisocial internet addicts, they use the internet for non-social purposes such as using the internet to cyberbullying other people, selling illegal or fake products on online media, deceiving others people, and using the internet for the purpose of illegal gambling (Ma, 2011).

Survey results in 2006 showed that adolescents use social media to stay connected with their friends and some of them to establish relationships with new friends (Lenhart, 2007). Individuals who use social media for the sake of social relations, usually they have a high social identity such as solidarity, compatibility with social groups, high altruism and an interest in being present in a virtual environment (Kwon \& Wen, 2010).

The use of the internet with social goals can make it easier to reach people, contribute to the ability to stay connected, make it easier to meet new people, increase the quantity of communication with others, make someone feel less isolated, help in connecting with friends and family, and to improve the quality of communication with others (Cotten et al., 2013).

Another reason young people use the internet comes from a high level of curiosity about information that makes them browse through internet access. Younger individuals are more likely to access the internet in obtaining the information than older individuals who tend to use traditional media such as print media and magazines to find sources of information (Jacobs et al., 2017; Tennant et al., 2015).

The internet may not be known and used in general, depending on technical and cultural readiness in its application. But the internet is believed to be an important source of information (Wei et al., 2003). Internet in its development became a change in the midst of society at large. In the era before the advent of the website, humans relied heavily on physical information, but after the advent of the web, many peoples turned to the web as a source of information search (Afzal, 2009; Rieh, 2004).

Online business is also the reason of young people often access the internet. There are some young people who spend their daily lives with selling online and making online purchases through internet networks that are directed at online buying and selling content or e-commerce. ECommerce is easier to implement than buying and selling in real life which is many times consuming and can have an impact on physical conditions. But buying and selling online also gives a bad impression because there is a tendency to not pay attention to how many items have been purchased so as to get closer to wasteful behavior (Gunuc \& Keskin, 2016). Addicted to online shopping is called pathological buying online, this model is part of internet addiction (Trotzke et al., 2015). So also with online shopping addiction that has many similarities with internet addiction related to measurement scale items (Zhao et al., 2017).

Online shopping behavior is related to seven predictors that might influence the behavior, namely low self-esteem, low self-regulation, negative emotions, enjoyment, gender, social anonymity and cognitive excessive (Rose \& Dhandayudham, 2014). Research conducted by Holden revealed that there were respondents who made the internet an opportunity for him to benefit from the results of selling online (Holden, 2012). These findings are consistent with the results of this study that young people make online businesses as a source of their financial income.

\section{Feelings Experienced without Internet Access}

Young people also admit that they feel anxious and lonely if they do not access online. That they experienced when at certain times that required them not to be able to access the internet, for example when the handphone signal was error, the handphone was in charge and had to be turned 
off, when it did not have an internet quota, the handphone was lost, and when attending the lesson in class became some of their reasons don't access the internet. Anxiety and loneliness arise from themselves after the need to access the internet is not met.

\begin{abstract}
"Just feeling anxious when not holding a handphone and not accessing the internet. Moreover, there are incoming messages or information that I have not accessed on the internet, it makes me very worried and anxiety what exactly is happening. Not only worry, I also often feel lonely when I am far from a handphone and do not access it online, because other people around are also busy with internet access on their mobile phones and laptops so that I never get satisfaction in establishing social interaction with the surrounding environment"
\end{abstract}

Internet addicts naturally experience such feelings above, Hakim and Raj (2017) said that when they are offline from the internet world, some feelings will emerge from themselves such as fear, anxiety, worried, confusion, boredom, panic, and sadness. Kashmir valley communities since 2016 have been banned from internet and cellular services. During these times, the lack of internet creates many problems for the community in addition to the positive impact it receives (Farooq, 2017).

A survey stated that $36.5 \%$ of respondents agreed that they would suffer a large loss if they did not get internet access (Kingsley \& Anderson, 1998). When addicts are forced not to access the internet, they will think "I must have it", "I can't go without it", and "I need it". This happens because the internet is a destination for individuals who experience internet addiction (Young, 2004).

Aside from experiencing anxiety, restless, and worry, living without the internet with someone who is addicted to the internet also makes him feel lonely. This was also confirmed by Cotten, Anderson, and McCullough. According to them, using the internet is beneficial to reduce loneliness in humans (Cotten et al., 2013). The internet addiction also has a relationship with human loneliness (Longstreet et al., 2019). Individuals tend to use the internet in establishing relationships with others when they feel lonely, but this can cause them to not be able to meet face by face with that person (Menelaou, 2017).

\title{
The Impact of Internet Access Continuously
}

The impact of accessing online for young people with internet addiction is related to their emotional feelings. Sometimes they feel happy or sad according to the context they experienced during accessing the internet. They feel happy and excited when they get the good news and get what they are looking for and they want in cyberspace. For those who like to play online games, winning in a tournament is make them satisfied and happy. Instead, feelings of sadness arise when getting bad news from friends, friendships, and family for themselves and do not get something they are looking for on the internet.

In addition to the impact on themselves that is emotional, playing the internet continuously also has an impact on his relationship with the surrounding environment such as difficulty in establishing direct social interaction with others and difficult for them to manage their time so that many tasks or jobs are neglected. 
"There are only two of my feelings when I often access the internet, which is happy and sad. I usually feel happy when I hear good news, for example the first time in a relationship with a couple while chatting with romantic words. In addition, I also feel happy when the expectations I want are realized when I am online. I have also felt sad when I heard bad news from friends, brothers, or family, and it also be hateful by a couples or friendship"

"In facts there is something else that I feel, as I felt it difficult to establish communication with friends and family around. When meeting, more from us busy holding handphone each other's than just talking about important things and remembering the past. In addition, many of my activities were neglected because I felt lazy and forgot when it was fun to access the internet and play online games. For example, forgetting that agreeing to an appointment to meet friends, lazy and feel sleepy to take lessons in the morning because it is caused by accessing online until late at night"

There is a significant relationship between internet addiction and human emotional condition. Internet addiction can increase negative emotions and reduce positive emotions. This is disturbing because internet users are increasing every time (Longstreet et al., 2019). Individuals with high internet addiction are associated with emotional problems they experience (Cerruti et al., 2017). Personality characteristics and emotional behavior of internet addicts are different from groups that are not addicted, internet addicts experience more negative emotions and emotional addiction (Xiao, 2018).

Negative emotions felt by young people with internet addiction because they tend to have no way to control themselves and control emotions in themselves, especially in young people who are addicted to virtual games (Kim et al., 2008). Internet addiction in young people has a positive relationship with their emotional instability, so that it can affect to their poor academic performance (Ambad et al., 2017).

Young people with internet addiction also felt difficult to control time in their daily lives (Xiao, 2018). Internet addiction has a moderate relationship with time management. The higher the internet addiction that is owned by individuals, the more difficult they are in managing time, so that the difficulty will have an impact on the academic performance of young people, both men and women (Siddiqi \& Memon, 2016). It was also justified by Vanea that internet addiction felt problems in time management and work performance (Vanea, 2011).

Malak (2018) in his findings explained that the difficulty of managing time in individuals who experience internet addiction can be corrected by using Cognitive Behavioral Therapy. The therapy is significant in improving the time management skills of internet addicts. This therapy can be used for several parties related to the process of development and education of young people in minimizing internet addiction that occurs to them.

Social relationships of young people who experience internet addiction do not work as expected. The results show that they have difficulty in establishing social relations with the surrounding environment. This was confirmed by Sato that the effect of internet addiction is that one of them 
will experience problem on social interactions with friends and family (Sato, 2006). Internet use has a negative impact on the development of social skills of young people. There are significant differences in social skills, social tolerance, and behavior patterns between users and non-users of the internet (Ibia \& Ekott, 2013). Relationship disorders with peers are occur more in men who are addicted to the internet than women who are internet addicts (Ong \& Tan, 2014).

There is an interesting explanation from Elavarasan et al (2018). They in their research explained that there were $52.2 \%$ of total individuals who were addicted to the internet experiencing social phobia. According to them, young people who are addicted to the internet are three times more likely to experience social phobia than individuals who are not addicted. However, the possibility that internet addiction experienced by individuals is also caused by the lack of support from the social environment, especially the lack of affection he gets from the surrounding environment (Savci \& Aysan, 2017).

Discuss about internet addiction will certainly direct our minds to a negative consequence that will be experienced than a positive consequence. The consequences they will experience such as social withdrawal, lack of relationships with peers and family, and psychological problems such as depression and anxiety, because some of these negative effects are often encountered in some case and in several other research findings (Malak, 2018). Game addicts through internet access show low social self-efficacy and interpersonal trust which measured by peer engagement (Blinka \& Mikuška, 2014).

The results of this study also show that a little boredom will arise when young people often use the internet in their daily excess. This is also as a response to the findings from Wang which states that excessive internet use is triggered by boredom when there is free time (Wang, 2018).

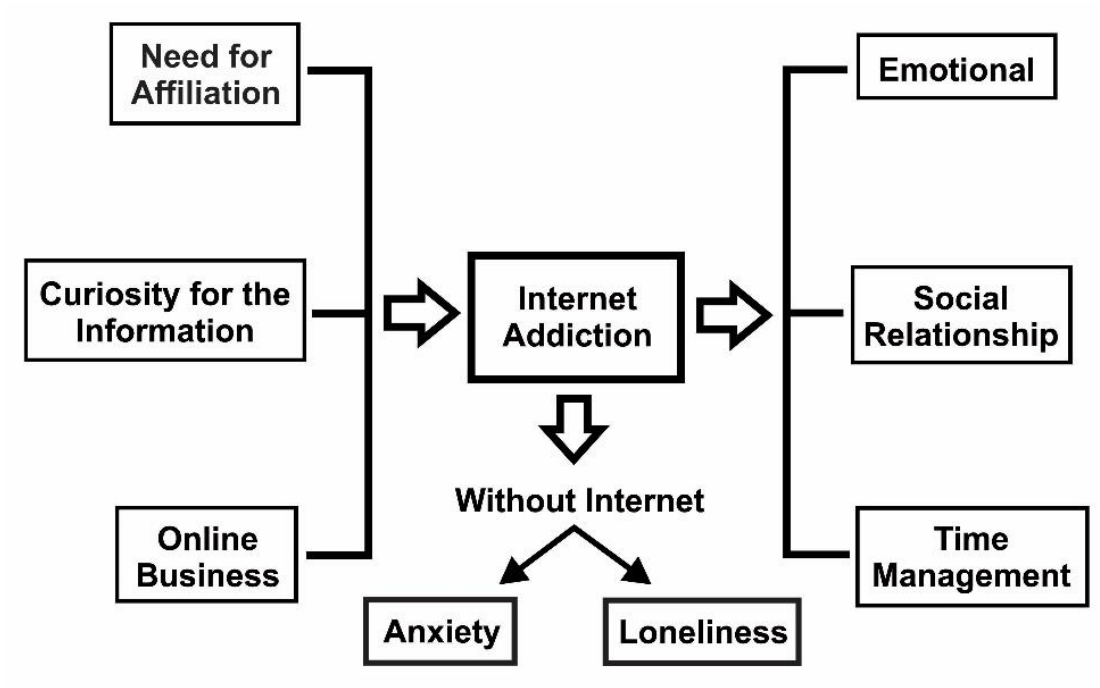

Figure 2. Psychological Dynamics of Youth with Internet Addiction 


\section{Conclusion}

Young people with internet addictions tend to access the internet often because they have high affiliation needs by assuming the internet can connect them with family and peers. Young people also use the internet as a source of information in facing global challenges. This is based on high curiosity among young people. Because through the web and several other features on the internet, all of knowledge and information will be easy to get by them. Online business is their next reason to remain under the influence of the internet. They can sell and buy products easily through online access that is connected to sellers and other buyers.

Anxious, worry, and feeling lonely always happens in young people who are addicted to the internet if they are separated from the internet, both those who are perforce condition (for example when a handphone or laptop is broken) or forced to not access online (for example forbidden prohibited from accessing the internet during attending lessons). The impact of excessive use of the internet will make young people who are addicted to the internet experience uncertain emotional conditions (sometimes happy, sad, worried), experiencing problem in establishing social relationships with the surrounding environment and difficulty managing time in daily life. Boredom also arises when they access the internet too often in their daily lives excessively.

Future research should be more focused on the study of the psychological dynamics of internet addiction that is more specific to certain internet addictions, such as social media addiction, online gaming addiction, online trading addiction and some activities that are in great demand when accessing the internet. This is important to be deepened by adjusting the age range that is not only focused on young people, but also in adulthood.

\section{References}

Adalier, A., \& Balkan, E. (2012). The relationship between internet addiction and psychological symptoms. International Journal of Global Education, 1(2). 42-49.

Afzal, W. (2009). Web for information seeking: A propositional study. Emporia State Research Studies, 45(2). 32-36.

Ambad, S. N. A., Kalimin, K. M., \& Yusof, K. M. A. A. K. (2017). The effect of internet addiction on students' emotional and academic performance. e-Academia Journal, 6(1), 86-98.

Ancona, L. (2009). Dynamic psychology. In S. Carta (Eds), Encyclopedia of Life Support Systems (EOLSS). Oxford: Eolss Publisher Co. Ltd.

APJII. (2018). Hasil survei penetrasi dan perilaku pengguna internet Indonesia 2018 (In Indonesian). Retrived from https://apjii.or.id/survei

Blinka, L., \& Mikuška, J. (2014). The role of social motivation and sociability of gamers in online game addiction. Cyberpsychology: Journal of Psychosocial Research on Cyberspace, 8(2), article 6. Doi: 10.5817/CP2014-2-6

Braun, V. and Clarke, V. (2006) Using thematic analysis in psychology. Qualitative Research in Psychology, 3 (2). Doi 10.1191/1478088706qp063oa 
Cerruti, R., Spensieri, V., Presaghi, F., Valastro, C., Fontana, A., \& Guidetti, V. (2017). An exploratory study on internet addiction, somatic symptoms and emotional and behavioral functioning in school-aged adolescents. Clinical Neuropsychiatry: Journal of Treatment Evaluation, 14(6), 374-383

Cotten, S. R., Anderson, W. A., \& McCullough, B. M. (2013). Impact of internet use on loneliness and contact with others among older adults: Cross-sectional analysis. Journal of Medical Internet Research, 15(2). Doi 10.2196/jmir.2306

Elavarasan, K., Dhandapani, T., Norman, P., Vidya, D. C., \& Mani, G. (2018). The association between internet addiction, social phobia and depression in medical college students. International Journal of Community Medicine and Public Health, 5(10), 4351-4356. Doi 10.18203/2394-6040.ijcmph20183973

Espejo, A., \& Espindola, E. (2016). The master key to the social inclusion of young people: education and employment. In D. Trucco \& H. Ullmann (Eds), Youth: Realities and Challenges for Achieving Development with Equality. Santiago: Economic Commission for Latin America and the Caribbean (ECLAC)

Farooq, T. (2017). Life without internet: A study from Kashmir. National Journal of Multidisciplinary Research and Development, 2 (2), 233-235.

Gancia, G. (2012). Globalization, technology, and inequality. Economic Working Papers. Department of Economics and Business, Universitat Pompeu Fabra.

Griffiths, M. (2005). A 'components' model of addiction within a biopsychosocial framework. Journal of Substance Use, 10 (4), 191-197. Doi 10.1080/14659890500114359

Griffiths, M. D., Kuss, D. J., \& Demetrovics, Z. (2014). Social networking addiction. Behavioral Addictions, 119-141. Doi:10.1016/b978-0-12-407724-9.00006-9

Gunuc, S., \& Keskin, A. D. (2016). Online shopping addiction: Symptoms, causes and effects. Addicta: The Turkish Journal on Addictions, 3(3), 353-364. Doi 10.15805/addicta.2016.3.0104

Hakim, S. N., \& Raj, A. A. (2017). Dampak kecanduan internet (internet addiction) pada remaja (In Indonesian). Paper presented at the Prosiding Temu Ilmiah $\mathrm{X}$ Ikatan Psikologi Perkembangan Indonesia.

Hartedja, S. E. (2016). Dinamika psikologis gamers yang mengalami kecanduan game online pada mahasiswa. (In Indonesian). Thesis. Catholic University of Widya Mandala, Surabaya, Indonesia.

Henze, V. (2015). On the concept of youth: some reflections on theory. In I.Schafer (Eds), Youth, revolt, recognition: The young generation during and after the "arab spring". Berlin: Mediterranean Institute Berlin (MIB)/HU Berlin.

Holden, M. (2012). Life with or without the internet: The domesticated experiences of digital inclusion and exclusion. Doctoral Dissertation. Published by Media@LSE, London School of Economics and Political Science ("LSE") 
Hootsuite \& We Are Social. (2019). Digital 2019: Essential insights into how people around the world use the internet, mobile devices, social media, and e-comerce. Retrieved September 27, 2019, from https://wearesocial.com/global-digital-report-2019

Ibia, I. E., \& Ekott, I. B. (2013). Internet usage and the development of social skills among youths in akwa ibom state, Nigeria. Sociology and Anthropology, 1(2). 65-71. Doi 10.13189/sa.2013.010204

Internet World Stats. (2019). Top 20 countries with the highest number of internet users. Retrieved September 27, 2019, from https://www.internetworldstats.com/top20.htm

Jacobs, W., Amuta, A. O., \& Jeon, K. C. (2017). Health information seeking in the digital age: An analysis of health information seeking behavior among US adults. Cogent Social Sciences, 3 (1), 1-11. Doi 10.1080/23311886.2017.1302785

Kempa, E. P. (2015). Social media addiction - The paradox of visibility \& vulnerability. University of Boras.

Kim, E. J., Namkoong, K., Ku, T., \& Kim, S. J. (2008). The relationship between online game addiction and aggression, self-control and narcissistic personality traits. European Psychiatry, 23(3), 212-218.

Kingsley, P., \& Anderson, T. (1998). Facing life without the Internet. Internet Research, 8 (4), $303-$ 312. Doi 10.1108/10662249810231041

Kuss, D. J., \& Griffiths, M. D. (2011). Online social networking and addiction-A review of the psychological literature. International Journal of Environmental Research and Public Health, 8(9), 3528-3552. Doi 10.3390/ijerph8093528

Kuss, D. J., Griffiths, M. D., Karila, L., \& Billieux, J. (2014). Internet addiction: A systematic review of epidemiological research for the last decade. Current Pharmaceutical Design, 20, $1-26$.

Kuss, D. J., Shorter, G. W., van Rooij, A. J., Griffiths, M. D., \& Schoenmakers, T. (2014). Assessing internet addiction using the parsimonious internet addiction components model. A preliminary study. International Journal of Mental Health and Addiction, 12(3). 351-366.

Kwon, O., \& Wen, Y. (2010). An empirical study of the factors affecting social network service use. Computers in Human Behavior, 26, 254-263.

Lenhart, A. (2007). Social networking websites and teens: An overview. Retrieved from http://www.pewinternet.org/ /media//Files/Reports/2007/PIP_SNS_Data_Memo_Jan_2007.p df.pdf

Liu, Y., Wang, J., Jiang, Y., Sun, J., \& Shang, J. (2018). Identifying impact of intrinsic factors on topic preferences in online social media: A nonparametric hierarchical Bayesian approach. Information Sciences, 423, 219-234.

Longstreet, P., Brooks, S., \& Gonzalez, E. S. (2018). Internet addiction: When the positive emotions are not so positive. Technology in Society, 57. 76-85. Doi 10.1016/j.techsoc.2018.12.004

Ma, H. K. (2011). Internet addiction and antisocial internet behavior of adolescents. The Scientific World Journal, 11, 2187-2196. Doi 10.1100/2011/308631 
Malak, M. Z. (2018). Internet addiction and cognitive behavioral therapy. Cognitive Behavioral Therapy and Clinical Applications. 183-199. Doi:10.5772/intechopen.71277

McKenzie, J. (2019). Introduction to the special issue: Globalization as a context for youth development. New Directions for Child and Adolescent Development, 164, 7-9. Doi 10.1002/cad.20276.

Medical Dictionary for the Health Professions and Nursing. (2012). Dynamic psychology. (n.d.). Retrieved July 23, 2019, from https://medicaldictionary.thefreedictionary.com/dynamic+psychology.

Menelaou, N. (2017). New media, time management and addiction. Journal of Media Critiques, 3(11), 145-152. Doi 10.17349/jmc117312.

Mihajlov, M., \& Vejmelka, L. (2017). Internet addiction: A review of the first twenty years. Psychiatria Danubina, 29(3). 260-272. Doi 10.24869/psyd.2017.260.

Murray, M. (2003). Narrative psychology and narrative analysis. In P. M. Camic, J. E. Rhodes, \& L. Yardley (Eds.), Qualitative research in psychology: Expanding perspectives in methodology and design (pp 95-112). Washington, DC, US: American Psychological Association. Doi 10.1037/10595-006.

Ong, S. H., \& Tan, Y. R. (2014). Internet addiction in young people. Annals Academy of Medicine, 43 (7), 378-382.

Poli, R. (2017). Internet addiction update: Diagnostic criteria, assessment and prevalence. Neuropsychiatry, 7(1), 4-8. Doi 10.4172/Neuropsychiatry.1000171

Rieh, S. Y. (2004). On the web at home: Information seeking and web searching in the home environment. Journal of the American Society for Information Science and Technology, 55(8), 743-753. Doi 10.1002/asi.20018.

Rose, S., \& Dhandayudham, A. (2014). Towards an understanding of Internet-based problem shopping behaviour: The concept of online shopping addiction and its proposed predictors. Journal of Behavioral Addictions, 3(2), 83-89. Doi:10.1556/jba.3.2014.003

Sandra, L. (2012). Dinamika psikologis interaksi konsep diri dan identitas online (In Indonesian). Doctoral Dissertation. Yogyakarta: Perpustakaan Pusat UGM.

Sato, T. (2006). Internet addiction among students: Prevalence and psychological problems in Japan. JMAJ, 49(7.8), 279-283.

Savci, M., \& Aysan, F. (2017). Social-emotional model of internet addiction. Psychiatry and Clinical Psychopharmacology, 27(4), 349-358. Doi:10.1080/24750573.2017.1367552.

Siddiqi, S., \& Memon, Z. A. (2016). Internet addiction impacts on time management that results in poor academic performance. Paper presented at 2016 International Conference on Frontiers of Information Technology (FIT), 63-68. Doi:10.1109/fit.2016.020.

Suny Levin Institute (2013). Technology and globalization. 1-47. Retrieved August 12, 2019, from http://www.globalization101.org/. 
Tennant, B., Stellefson, M., Dodd, V., Chaney, B., Chaney, D., Paige, S., \& Alber, J. (2015). eHealth literacy and web 2.0 health information seeking behaviors among baby boomers and older adults. Journal of Medical Internet Research, 17, e70. Doi 10.2196/jmir.3992.

Trotzke, P., Starcke, K., Müller, A., \& Brand, M. (2015). Pathological Buying Online as a Specific Form of Internet Addiction: A Model-Based Experimental Investigation. PLOS ONE, 10(10). Doi 10.1371/journal.pone.0140296.

UU Kepemudaan. (2009). Undang-undang Republik Indonesia tentang kepemudaan. No 40 tahun 2009 bab 1 pasal 1 no 1 (In Indonesian).

Vanea, M. O. (2011). Intensive / excessive use of internet and risks of internet addiction among specialized workers - gender and online activities differences. Procedia - Social and Behavioral Sciences, 30, 757-764. Doi 10.1016/j.sbspro.2011.10.148.

Veronica, S. A., \& Samuel, A. U. (2015). Social media addiction among adolescents with special reference to facebook addiction. Journal of Humanities and Social Science (IOSR-JHSS), 4, 72-76.

Wainner, C. N. (2018). Social media addiction and its implications for communication. Thesis. University of Tennessee Honors.

Wallace, P. (2014). Internet addiction disorder and youth. EMBO Reports, 15(1), 12-16. Doi 10.1002/embr.201338222.

Wang, W. C. (2018). Exploring the relationship among free-time management, leisure boredom, and internet addiction in undergraduates in Taiwan. Psychological Reports, O(0), 1-15. Doi $10.1177 / 0033294118789034$.

Wei, C. Y., Kolko, B. E., \& Spyridakis, J. H. (2003). Information-seeking behavior and internet use in Uzbekistan. Department of Technical Communication, University of Washington.

Wilig, C. (2008). Introducing qualitative research in psychology: Second edition. England: Open University Press

Xiao, G. (2018). Psychological mechanism of adolescent internet addiction and brain functional imaging. NeuroQuantology, 16(5), 915-920. Doi 10.14704/nq.2018.16.5.1422.

Young, K. S. (2004). Internet Addiction. American Behavioral Scientist, 48(4), 402-415. Doi $10.1177 / 0002764204270278$.

Young, K. S. (1999). Internet addiction: Symptoms, evaluation, and treatment innovations in clinical practice. In L. VandeCreek, \& T. L. Jackson (Eds.), Innovations in Clinical Practice, (Volume 17) Sarasota, FL: Professional Resource Press.

Zhao, H., Tian, W., \& Xin, T. (2017). The development and validation of the online shopping addiction scale. Frontiers in Psychology, 8. 1-9. Doi 10.3389/fpsyg.2017.00735.

Zolkepli, I. A., \& Kamarulzaman, Y. (2015). Social media adoption: The role of media needs and innovation characteristics. Computers in Human Behavior, 43, 189-209. 